\title{
Bacteriologically confirmed extra pulmonary tuberculosis and treatment outcome of patients consulted and treated under program conditions in the littoral region of Cameroon
}

\author{
Teyim Pride Mbuh ${ }^{1,3^{*}}$ D, Irene Ane-Anyangwe ${ }^{1}$, Wandji Adeline ${ }^{3}$, Benjamin D. Thumamo Pokam²,
} Henry Dilonga Meriki ${ }^{1}$ and Wilfred Fon Mbacham ${ }^{4}$

\begin{abstract}
Background: Extra-pulmonary tuberculosis (EPTB) is defined as any bacteriologically confirmed or clinically diagnosed case of TB involving organs other than the lungs. It is frequently a diagnostic and therapeutic challenge with paucity of data available. The aim of this study was to assess the prevalence of bacteriologically confirmed EPTB; to determine the most affected organs and to evaluate the therapeutic outcome of EPTB patients treated under program conditions in the littoral region of Cameroon.
\end{abstract}

Methods: A descriptive cross-sectional laboratory-based epidemiological survey was conducted from January 2016 to December 2017 and 109 specimens from 15 of the 39 diagnosis and treatment centers in the littoral region were obtained.

Two diagnostic methods (Gene Xpert MTB and culture (LJ and MGIT) were used for EPTB diagnosis. Determine HIV1/2 and SD Biolinewere used for HIV diagnosis. Confirmed EPTB cases were treated following the national tuberculosis guide.

Results: The prevalence of bacteriologically confirmed EPTB was $41.3 \%$ (45). All 45 cases were sensitive to rifampicin. Males were predominately more infected [26 (57.8\%)] likewise the age group 31-45 years with 15 (33. 3\%) cases. The overall prevalence for HIV was 33.6\% (36). HIV infection was present in $28.9 \%$ (13) of patients with EPTB. The most affected sites with EPTB were: Lymph nodes (66.5\%), pleural cavity (15.6\%), abdominal organs (11. $1 \%)$, neuromeningeal (2.2\%), joints (2.2\%) and heart (2.2\%). Overall, $84.4 \%$ of the study participants had a therapeutic success with males responding better $57.9 \%(p=0.442)$. Therapeutic success was better $(71.7 \%)$ in HIV negative EPTB patients $(p=0.787)$.

Conclusion: The prevalence of bacteriologically confirmed EPTB patients treated under program conditions in the littoral region of Cameroon is high with a therapeutic success of $84.4 \%$ and the lymph nodes is the most affected site.

Keywords: Gene xpert MTB/RIF, Extra pulmonary TB, Treatment outcome, Littoral region Cameroon

\footnotetext{
* Correspondence: teyimpride@yahoo.com

${ }^{1}$ Department of Microbiology and Parasitology, Faculty of Science, University

of Buea, Buea, Cameroon

${ }^{3}$ Tuberculosis Reference Laboratory, Douala, Littoral Region, Cameroon

Full list of author information is available at the end of the article
}

(c) The Author(s). 2019 Open Access This article is distributed under the terms of the Creative Commons Attribution 4.0 International License (http://creativecommons.org/licenses/by/4.0/), which permits unrestricted use, distribution, and reproduction in any medium, provided you give appropriate credit to the original author(s) and the source, provide a link to the Creative Commons license, and indicate if changes were made. The Creative Commons Public Domain Dedication waiver (http://creativecommons.org/publicdomain/zero/1.0/) applies to the data made available in this article, unless otherwise stated. 


\section{Background}

Tuberculosis (TB) is a leading cause of morbidity and mortality worldwide, accounting for about 9.6 million new cases and 1.5 million deaths annually [1].

Pulmonary TB represents about $70 \%$ of all cases of TB and is the most contagious form $\mathrm{TB}$ and remains the main target for TB control [2, 3]. Extra-pulmonary tuberculosis (EPTB) defined as any bacteriologically confirmed or clinically diagnosed case of TB involving organs other than the lungs. The description of a form of EPTB is a function of its location affecting the pleura, lymph nodes, abdomen, genitourinary tract, skin, joints and bones, meninges.

EPTB represents 15 to $30 \%$ of all forms of tuberculosis $[4,5]$, and is frequently a diagnostic and therapeutic challenge. It is a common opportunistic infection in people living with HIV/AIDS and other immunocompromised states [6]. The immune suppression status of these persons results in dissemination of the bacteria form the lungs to other organs. There is a paucity of data on bacteriological diagnosis and therapeutic evaluation on EPTB in Cameroon.

The objective of this study was to assess the prevalence of bacteriologically confirmed EPTB; to determine the most affected organs and to evaluate the therapeutic outcome of EPTB patients treated under program conditions in the littoral region of Cameroon.

\section{Methods}

We conducted a descriptive cross-sectional hospital-based epidemiological survey from January 2016 to December 2017. A non-probabilistic accidental sampling method was used to obtain 145 non sputum specimens and 145 venous blood in dry tubes from 80 male and 65 female participants suspected for EPTB and consulting 15 of the 39 diagnostic and treatment centers (DTCs) in the Littoral region of Cameroon. The littoral region was chosen because it harbours about $20 \%$ of all TB diagnosed cases in Cameroon and also because it is the economic head quarter of Cameroon and Douala the regional head quarter is the largest city in Cameroon with a population of $1,338,082$ people. It harbors many referral diagnostic and treatment institutions that pulls many persons from the regions in search for better health service. A total of 36 participants were rejected due to incomplete request forms. 109 (57 male and 52 female) participants were finally retained and analyzed for this study. Verbal Consent of participant was sort during clinical consultation. For participants younger than 15 years; consent was obtained from parent/legal representative. Authorizations for this study were obtained from the permanent secretary for national tuberculosis control program and ethical clearance was obtained from the University of Douala's ethical review board.
EPTB specimens (plural fluid, cerebrospinal fluid, synovial fluid, ascites and lymph node aspirate) obtained from participants were aliquoted and analyzed on Gene Xpert MTB/RIF. This system integrates and automates sample processing, nucleic acid amplification, and detection of the target sequences. The primers in the XpertMTB/RIF assay amplify a portion of the $r p o B$ gene containing the 81 base pair "core" region. The probes are able to differentiate between the conserved wild-type sequence and mutations in the core region that are associated with rifampicin resistance. The aliquoted specimen was decontaminated using $3 \% \mathrm{NaOH}$ and the pellet inoculated on MGIT and grown in BACTEC 960 for 42 days. Positive MGIT samples were further subjected to Gene Xpert MTB/RIF for confirmation and Rifampicin drug susceptibility testing. A positive diagnosis for EPTB was declared when direct Gene XpertMTB/RIF and or culture results were positive.

Bacteriologically confirmed EPTB cases were treated following the national tuberculosis guide which recommended that new cases should be treated for 6 months consisting of 2 months of daily rifampicin (R), isoniazide $(\mathrm{H})$, pyrazinamide $(\mathrm{Z})$ and ethambutol (E) (intensive phase), followed by 4 months of daily RH (2RHZE/4RH). Retreatment cases [relapses, treatment failure cases, defaulters) should be treated for 2 month with RHZE and streptomycin $(\mathrm{S})$, and a third month without $\mathrm{S}$ (intensive phase), followed by 5 months of RHE daily (2RHZES/ 1RHZE/5RHE). At the end of treatment, treatment outcome was categorized as cured, completed treatment, lost to follow up, failure and died based on the standard criteria [7].

HIV screening was done by testing serum from coagulated blood collected in dry tubes on Determine HIV 1/2 striptest. Positive samples were confirmed on rapid SD BiolineHIV 1/2 3.0 cassettes.

Data was analyzed using SPSS version 16.0 software (Statistical Package for Social Science). Percentage accuracy, sensitivity, specitivity, positive predictive values, and negative predictive values were manually calculated as follows:

(\%) Accuracy $=$ number of correct results / total number of results $\mathrm{X} 100$,

(\%) Sensitivity = number of true positive results/ number of true-positive plus false-negative results X 100,

(\%) Specificity = number of true negative results/ number of true-negative plus false positive results X 100 .

(\%) Positive Predictive Value = number of true-positive results/ number of true-positive plus false-positive results X 100 .

(\%) Negative Predictive Value $=$ number of true negative results / number of true-negative results plus false negative results X 100; and statistically significant was set at $p<0.05$. 


\section{Results}

Table 1 shows the socio-demographic characteristics of 109 study participants. The median age of study participant was $40.0 \pm 19.23$ years with females being relatively younger ( $35.5 \pm 20.0$ years) than their male counterparts $45.0 \pm 18.3$ years). Thirty six $(33.6 \%)$ of the study population were infected with HIV-1. The prevalence of bacteriologically confirmed EPTB in the study was 45 $(41.3 \%)$, and all the subjects were sensitive to rifampicin. Of the 45 cases, a male predominance [26 (57.8\%)] was observed $(P=0.336)$. The EPTB/HIV co-infection rate was $13(28.9 \%)$. The most affected age group was that of $35-51$ years with 15 (33.3\%) cases recorded followed by that of $18-34$ years with 14 (31.1\%). Those who had no treatment history for TB represented $66.6 \%$ of the study population as illustrated on Table 2 .

The most affected site were the lymph nodes 31/109 $(68.9 \%)$ and there was a statistically significant different between the positivity of lymph node aspirates and all other EPTB specimens tested [ $p=0.001$, CI 55.4-82.4, $\mathrm{OR}=$ ] this was closely followed by the pleural cavity 7 (15.6\%) as illustrated on Fig. 1. Based on both diagnostic methods used in our study, the overall prevalence of extra pulmonary tuberculosis was 45 (41.3\%). There was a positive discordance in 7 cases, and negative discordance in 4 cases as illustrated in Table 3.

By observing the treatment outcome of the studied participants, we found that $38(84.4 \%)$ cases have completed the treatment course. Five $(11.1 \%)$ cases died before completing the course and were all EPTB/HIV co-infected. Two (4.2\%) cases were loss to follow up and no defaulter or relapse cases were recorded.

Overall, $84.4 \%$ of these participants had a therapeutic success with males responding better $22(57.9 \%)$ as oppose to females16 (42.1\%) $(p=0.442)$. Therapeutic success $[27(71.7 \%)]$ was better in HIV negative EPTB patients compared to HIV positive [11(28.1)] patients ( $p=$ 0.787). With respect to site, treatment completion rate was observed as follows: lymph node 25 (83.3\%), pleural effusion 7 (100\%), abdominal organs 4(80\%), joints $1(100 \%)$, neuromeningeal $1(100 \%)$ and the heart $0(0 \%)$ as shown on Table 4.

\section{Discussion and conclusion}

This study was aimed at determining the prevalence of bacteriologically confirmed EPTB; to determine the most affected organs and to evaluate the treatment outcome of EPTB patients. Though the sampling method was non-probabilistic (not give all those visiting the study sites equal chances of participating in our study), we still thing these findings are of epidemiological importance.

The prevalence of bacteriologically confirm EPTB in this study was high $(41.3 \%)$. This finding is similar to those of Luma [8], were they found a prevalence of EPTB to be $42.9 \%$ amongst patients registered for anti-TB treatment in the general hospital of Douala in the same country. This was however higher than the 23.2\% reported by Yone et al., [9] in Yaoundé-Cameroon. This high prevalence of EPTB reported in our study could be partially justified by the elevated (33.6\%) prevalence of HIV in our study participant. HIV has be known to facilitates the dissemination of Mycobacterium tuberculosis out of the lungs and the reactivation of infection in extra-pulmonary organs [10]. Bacteriological confirmation of EPTB is a very challenging issue in most national tuberculosis programs because of the pauci-bacillary nature of the disease, the apportioning of the sample for various diagnostic tests resulting in

Table 1 Socio-demographic characteristics of study participants

\begin{tabular}{|c|c|c|c|}
\hline Characteristics & Category & Frequency & Percentage \\
\hline \multirow[t]{4}{*}{ Age range (years) } & $<18$ & 10 & 9.2 \\
\hline & $18-34$ & 31 & 28.4 \\
\hline & $35-51$ & 39 & 35.8 \\
\hline & $>51$ & 29 & 26.6 \\
\hline \multirow[t]{2}{*}{ Gender } & Female & 52 & 47.7 \\
\hline & Male & 57 & 52.3 \\
\hline \multirow[t]{2}{*}{ Treatment History } & Yes & 34 & 31.2 \\
\hline & No & 75 & 68.8 \\
\hline \multirow[t]{2}{*}{ HIV } & Positive & 36 & 33.0 \\
\hline & Negative & 71 & 65.1 \\
\hline \multirow[t]{4}{*}{ Patient type } & New & 75 & 68.8 \\
\hline & Relapse & 27 & 24.8 \\
\hline & Return after loss to follow up & 4 & 3.7 \\
\hline & Failure & 3 & 2.8 \\
\hline
\end{tabular}


Table 2 Distribution extra pulmonary tuberculosis (EPTB) according to sociodemographic and clinical characteristics of study participants

\begin{tabular}{|c|c|c|c|c|c|c|}
\hline \multirow{2}{*}{$\begin{array}{l}\text { Characteristics of } \\
\text { participant }\end{array}$} & \multirow[t]{2}{*}{ Category } & \multirow[b]{2}{*}{$\mathrm{N}$} & \multirow[b]{2}{*}{ Positive (\%) } & \multicolumn{3}{|l|}{ EPTB results } \\
\hline & & & & Negative (\%) & $\left(95 \% \mathrm{Cl}_{i}\right)$ & $p$-value \\
\hline \multirow[t]{4}{*}{ Age range (years) } & $<18$ & 10 & $7(15.6)$ & $3(4.7)$ & $35.8-97.4$ & 0.244 \\
\hline & $18-34$ & 31 & $14(31.1)$ & $19(26.6)$ & $27.4-60.8$ & \\
\hline & $35-51$ & 33 & $15(33.3)$ & $24(37.5)$ & $25.6-59.3$ & \\
\hline & $>51$ & 29 & $9(20.0)$ & $20(31.2)$ & $14.6-45.9$ & \\
\hline \multirow[t]{2}{*}{ Gender } & Male & 57 & $26(45.6)$ & $31(54.4)$ & $32.7-58.5$ & 0.336 \\
\hline & Female & 52 & $19(36.5)$ & $33(63.5)$ & $23.5-49.6$ & \\
\hline \multirow[t]{2}{*}{ HIV } & Positive & 36 & $13(28.9)$ & $23(37.1)$ & $23.6-57.6$ & .375 \\
\hline & Negative & 71 & $32(71.1)$ & $39(62.9)$ & $39.1-62.3$ & \\
\hline \multirow[t]{2}{*}{ Treatment History } & Yes & 34 & $15(44.1)$ & $19(55.9)$ & $27.4-60.8$ & 0.421 \\
\hline & No & 75 & $30(40.0)$ & $45(60.0)$ & $28.9-51.1$ & \\
\hline \multirow[t]{4}{*}{ Patient type } & New & 75 & $30(40.0)$ & $45(60.0)$ & $28.9-51.1$ & 0.706 \\
\hline & Relapse & 27 & $12(44.4)$ & $15(55.6)$ & $25.7-63.2$ & \\
\hline & Return after loss to follow up & 4 & $1(25.0)$ & $3(75.0)$ & $17.4-67.4$ & \\
\hline & Failure & 3 & $2(66.7)$ & $1(33.3)$ & 13.3-20.2 & \\
\hline
\end{tabular}

non-uniform distribution of microorganisms, the difficulty to obtain an adequate sample, the variable clinical presentation, and need for invasive procedures to secure appropriate sample [11], lack of laboratory facilities in the resource-limited settings and the lack of an efficient sample processing technique universally applicable on all types of extra-pulmonary samples [12]. All these limitations cause poor contribution of bacteriological techniques in the establishment of EPTB diagnosis [13].The male gender was predominantly more represented than the female gender. Those aged from 35 to 51 years old were also the most infected. These findings are similar to those of Kiran [14] in Morocco who found a significant male predilection (59.3\%). The relative higher incidence in males could be attributed to more exposure of the male gender to the external environment for their jobs especially as they are the principal bread winners in resource limited counties.

We found that lymph node involvement was the most common site of infection. This was different from recent

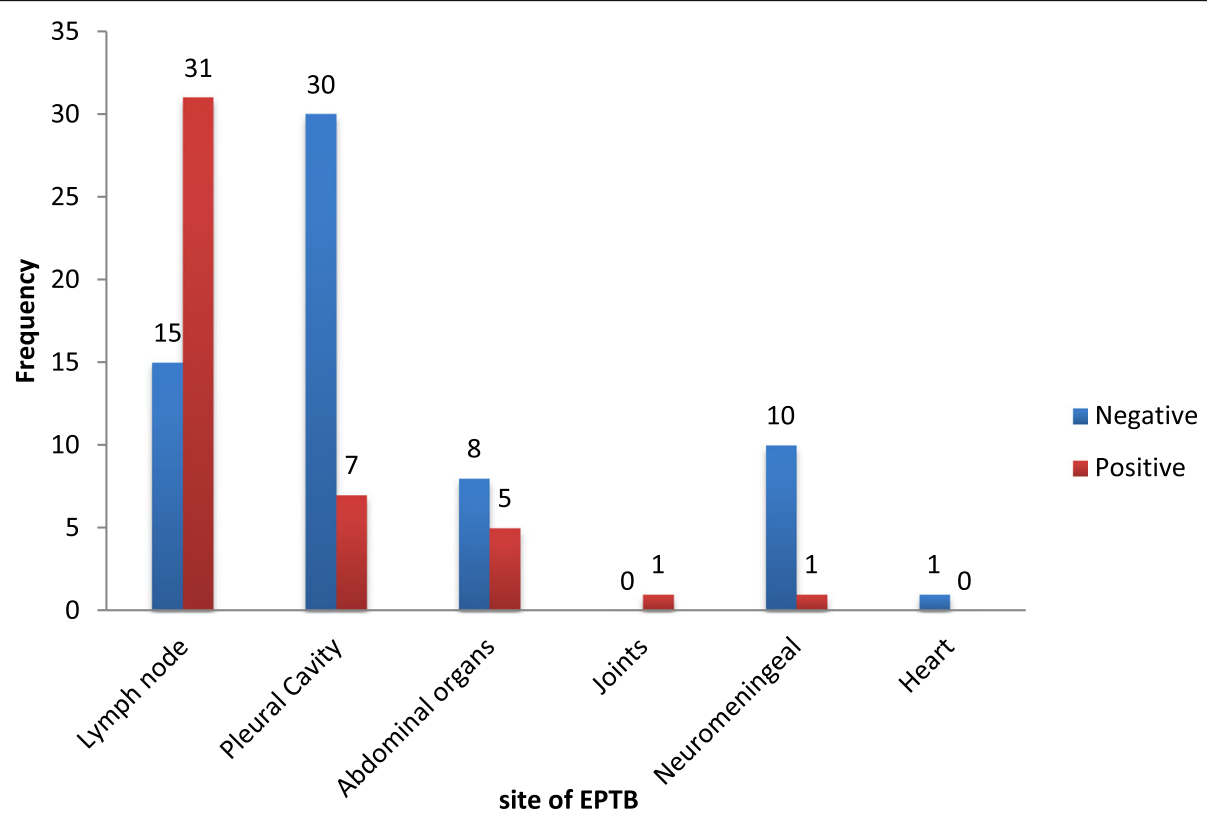

Fig. 1 Prevalence of extra pulmonary tuberculosis according to the organ sites affected 
Table 3 Comparison of diagnostic efficacy of Extra pulmonary using Gene Xpert and culture

\begin{tabular}{|c|c|c|c|c|c|c|c|c|c|}
\hline Specimen type & $\mathrm{N}$ & Culture & $\begin{array}{l}\text { Gene Xpert } \\
\text { Negative (\%) }\end{array}$ & $\begin{array}{l}\text { Gene Xpert } \\
\text { Positive (\%) }\end{array}$ & $\begin{array}{l}\text { Accuracy } \\
(95 \% \text { Cl) }\end{array}$ & $\begin{array}{l}\text { Sensitivity } \\
(95 \% \mathrm{Cl})\end{array}$ & $\begin{array}{l}\text { Specificity } \\
(95 \% \mathrm{Cl})\end{array}$ & $\begin{array}{l}\text { PPV } \\
(95 \% \text { Cl) }\end{array}$ & $\begin{array}{l}\text { NPV } \\
(95 \% \mathrm{Cl})\end{array}$ \\
\hline \multirow[t]{2}{*}{ Lymph Node Aspirates } & 46 & Negative & $15(32.6)$ & $4(8.7)$ & 84.8 & 88.9 & 78.9 & 85.7 & 83.3 \\
\hline & & Positive & $3(6.5)$ & $24(52.2)$ & $74.4-95.2$ & $77.1-100$ & $60.6-97.3$ & $72.8-98.7$ & $66.1-98.2$ \\
\hline \multirow[t]{2}{*}{ Pleural Fluid } & 37 & Negative & $30(81.2)$ & $2(5.4)$ & 91.9 & 0.8 & 93.8 & 66.7 & 96.8 \\
\hline & & Positive & $1(2.7)$ & $4(10.8)$ & $83.1-100$ & $44.9-98.2$ & $85.4-100$ & 28.9-100 & $90.5-100$ \\
\hline \multirow[t]{2}{*}{ Ascites } & 13 & Negative & $8(61.5)$ & $1(7.7)$ & 92.3 & 100 & 88.9 & 80 & 100 \\
\hline & & Positive & $0(0)$ & $4(3.08)$ & $77.8-100$ & $100-100$ & $68.4-100$ & $44.9-100$ & $100-100$ \\
\hline \multirow[t]{2}{*}{ Synovial Fluid } & 2 & Negative & $0(0)$ & $1(100)$ & 50 & 100 & & 50 & \\
\hline & & Positive & $0(0)$ & $1(50)$ & $19.3-19.3$ & $100-100$ & & $19.3-19.3$ & \\
\hline \multirow[t]{2}{*}{ Cerebrospinal fluid } & 11 & Negative & $10(90.9)$ & $0(0)$ & 100 & 100 & 100 & 100 & 100 \\
\hline & & Positive & $0(0)$ & $1(9.1)$ & $100-100$ & $100-100$ & $100-100$ & $100-100$ & 100-100 \\
\hline \multirow[t]{2}{*}{ Pericardial Fluid } & 1 & Negative & $1(100)$ & $0(0)$ & 100 & & 100 & & 100 \\
\hline & & Positive & $0(0)$ & $0(0)$ & $100-100$ & & $100-100$ & & 100-100 \\
\hline \multirow[t]{2}{*}{ Total specimens } & 109 & Negative & $64(58.7)$ & $7(6.4)$ & 89.0 & 89.2 & 90.15 & 82.5 & 94.1 \\
\hline & & Positive & $4(3.7)$ & $34(31.2)$ & $84.3-95$ & 79.7-99.2 & $83.2-97.1$ & 71.4-94.4 & $88.5-99.7$ \\
\hline
\end{tabular}

$\mathrm{Cl}$ confidence interval, $P P V$ positive predictive value, NPV Negative predictive value

studies $[8,15]$ where they found that the pleural and bones/joints were the most common site affected respectively. Our findings where however in line with other studies [15-17], who also reported lymph node involvement as the most affected EPTB site. This findings could be partially justified by the fact that we worked with several health facilities contrary to the Luma's study who worked in a single health facility [8].

Even though culture is considered the gold standard in TB diagnostics, growth on solid culture media requires four to six weeks. This delay would negatively affect patient care. To overcome this problem, we opted for automated cartridge-based molecular nucleic acid amplification (NAA) techniques, which offer a rapid diagnosis of life-threatening disease such as TB meningitis with a turnaround time of $24 \mathrm{~h}$. This method is said to be very sensitive as it can detect as few as 10 mycobacteria [13]. There was a positive discordance in 7 cases, and negative discordance in 4 cases with MGIT cultures. Other studies [12, 14, 18], however report very varying sensitivity and specificity of molecular nucleic acid amplification techniques in comparison with culture.

EPTB treatment success rate in this study was high and identical to the nationwide pulmonary TB therapeutic success rate of 75 to $84 \%$ reported in 2006 to $2015[19,20]$. This could be attributed to the fact that

Table 4 Therapeutic outcome of EPTB with respect of site of infection and HIV status

\begin{tabular}{|c|c|c|c|c|}
\hline site of infection & HIV Status & Died (\%) & Complete (\%) & Loss to Follow up (\%) \\
\hline \multirow[t]{2}{*}{ Lymph node } & Negative & $0(0)$ & $17(68)$ & $1(100)$ \\
\hline & Positive & $4(100)$ & $8(32)$ & $0(0)$ \\
\hline \multirow[t]{2}{*}{7 Pleural Cavity } & Negative & $0(0)$ & $6(85.7)$ & $0(0)$ \\
\hline & Positive & $0(0)$ & $1(14.3)$ & $0(0)$ \\
\hline \multirow[t]{2}{*}{5 Abdominal organs } & Negative & $0(0)$ & $3(75)$ & $1(100)$ \\
\hline & Positive & $0(0)$ & $1(25)$ & $0(0)$ \\
\hline \multirow[t]{2}{*}{1 Joints } & Negative & $0(0)$ & $0(0)$ & $0(0)$ \\
\hline & Positive & $0(0)$ & $1(100)$ & $0(0)$ \\
\hline \multirow[t]{2}{*}{1 Neuromeningeal } & Negative & $0(0)$ & $1(100)$ & 00 \\
\hline & Positive & $0(0)$ & $0(0)$ & $0(0)$ \\
\hline \multirow[t]{2}{*}{1 Heart } & Negative & $0(0)$ & $0(0)$ & $0(0)$ \\
\hline & Positive & $1(100)$ & $0(0)$ & $0(0)$ \\
\hline \multirow[t]{2}{*}{ All Sites } & Negative & $1(20)$ & $27(71.7)$ & $2(100)$ \\
\hline & Positive & $4(80)$ & $11(28.1)$ & $0(0)$ \\
\hline
\end{tabular}


we assigned a staff to call our patients very regularly to ensure that they all complied to their treatment even when they no longer felt sick; thought this is not always feasible in real life setting. This finding was in line with the stop TB strategy united nations millennium development goals to cure at least $85 \%$ of sputum smear-positive TB patients [21].

This study established that treatment success of EPTB patients co-infected with HIV was lower (28.1\%) compared to TB-HIV negative patients $(71.7 \%)$ and this is in line with Atekem, et al [22] in the South West region of Cameroon, but contrary to that of Mekonnenet al. [23] in North Eastern Ethiopia. Therapeutic success in this study was relatively high because we assigned a staff to call our patients very regularly to ensure that they all complied to their treatment even when they no longer felt sick. All the patients who died in this study were HIV positively co-infected, but the numbers were too small for a proper analysis. We thing that these patients may not have been compliant to their treatment and turned to neglect the regimen as they thought having HIV is the end of life. Furthermore, a weaken immune system may justify the death cases recorded in these HIV positive cases.There was no significant different between males and females and across the different age groups.

\section{Conclusion}

The prevalence of bacteriologically confirmed EPTB patients treated under program conditions in the littoral region of Cameroon is high with a therapeutic success of $84.4 \%$ and the lymph nodes is the most affected site.

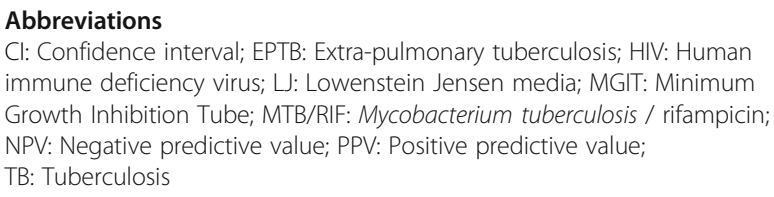
immune deficiency virus; LJ: Lowenstein Jensen media; MGIT: Minimum Growth Inhibition Tube; MTB/RIF: Mycobacterium tuberculosis / rifampicin; NPV: Negative predictive value; PPV: Positive predictive value; TB: Tuberculosis

\section{Acknowledgements}

Special thanks to the permanent secretary of the National Tuberculosis Program in Cameroon who permitted us to work in 15 of the 39 diagnostic and treatment centers in the Littoral region.

We also wish to thank all the staffs of the 15 diagnostic and treatment centers who assisted us with specimen collection drug administration and treatment monitoring

\section{Funding}

No funding was obtained for this study.

\section{Availability of data and materials}

The datasets used and/or analysed during the current study are available from the corresponding author on reasonable request.

\section{Authors' contributions}

TPM, IAA, WA and WFM participated in conception and design of the study. TPM collected the data. TPM, BTB and HDM analysis and interpretation of the data and also drafted the article. All authors revised and approved the final version.

\section{Ethics approval and consent to participate}

Verbal Consent of participant was sort during clinical consultation and for participant younger than 15 years, consent was obtained from parent/legal representative. Ethical clearance was obtained from the institutional ethics committee for research on humans of the University of Douala with ref. $N^{\circ}$. 1257 IEC-Udo/02/2016/T.

Consent for publication

Not applicable

\section{Competing interests}

I testify on behalf of all co-authors that our article submitted to the Journal BMC pulmonary medicine that:
$>$ This manuscript has not been submitted to, nor is under review at, another journal or other publishing venue.
$>$ The authors have no affiliation with any organization with a direct or indirect financial interest in the subject matter discussed in the manuscript

\section{Publisher's Note}

Springer Nature remains neutral with regard to jurisdictional claims in published maps and institutional affiliations.

\section{Author details}

'Department of Microbiology and Parasitology, Faculty of Science, University of Buea, Buea, Cameroon. ${ }^{2}$ Department of Medical Laboratory Science, Faculty Health Sciences, University of Buea, Buea, Cameroon. ${ }^{3}$ Tuberculosis Reference Laboratory, Douala, Littoral Region, Cameroon. ${ }^{4}$ Laboratory for Public Health Research Biotechnologies, Biotechnology Centre, University of Yaoundé, Yaoundé, Cameroon.

Received: 17 August 2018 Accepted: 19 December 2018 Published online: 17 January 2019

\section{References}

1. Raviglione M, Sulis G. Tuberculosis 2015: burden, challenges and strategy for control and elimination. Infect Dis Rep. 2016;8(2):33-7.

2. WHO. Global tuberculosis report. 2015;20:1-4. http://www.who.int/iris/ handle/10665/191102.

3. WHO. Tuberculosis annual report. In 2013. p. 1-37.

4. Ramirez-Lapausa M, Menendez-Saldana A. AN-A. Extrapulmonary tuberculosis : an overview. Rev Esp Sanid Penit. 2015:17:3-11.

5. Pollett S, Banner P, O'Sullivan MVN, Ralph AP. Epidemiology, diagnosis and management of extra-pulmonary tuberculosis in a low-prevalence country: a four year retrospective study in an Australian tertiary infectious diseases unit. PLoS One. 2016:11(3).

6. WHO. Global tuberculosis report. France; 2017. p. 63-97.

7. NTP-Cameroon. National Tuberculosis Strategic Plan 2010-2014 [Internet]. Yaounde; 2014. p. 9. Available from: http://www.nationalplanningcycles.org/ sites/default/files/planning_cycle_repository/cameroon/ nationaltuberculosisstrategicplan2010.pdf.

8. Namme LH, Marie-Solange D, Bertrand MN, Elvis T, Achu JH, Christopher K. Extrapulmonary tuberculosis and HIV coinfection in patients treated for tuberculosis at the Douala general hospital in Cameroon year. Ann Trop Med public Heal. 2013;06(01):100-4

9. Yone EW, Kengne AP, Moifo B, Kuaban C. Prevalence and determinants of extrapulmonary involvement in patients with pulmonary tuberculosis in a Sub-Saharan African country: A cross-sectional study. Scand J Infect Dis. 2013;45(2):104-11.

10. Jones BE, Young SM, Antoniskis D, Davidson PT, Kramer FBP. Relationship of the manifestations of tuberculosis to CD4 cell counts in patients with human immunodeficiency virus infection. Am Rev Respir Dis. 1993;148: $1292-7$.

11. Purohit M, Mustafa T. Laboratory diagnosis of extra-pulmonary tuberculosis (EPTB) in resource-constrained setting: State of the art, challenges and the need. J Clin Diagnostic Res. 2015:9(4):1-6.

12. Manjunath N, Shankar P, Rajan L, Bhargava A, Saluja SS. Evaluation of a polymerase chain reaction for the diagnosis of tuberculosis. Tubercle. 1991; 72(1):21-7. 
13. Maurya AK, Kant S, Nag VL, Kushwaha RADT. Trends of anti-tuberculosis drug resistance pattern in new cases and previously treated cases of extrapulmonary tuberculosis cases in referral hospitals in northern India. J Postgr Med. 2012;58(3):185-9.

14. Chawla K, Johar R, Shashidhar Vishwanath CM. Role of PCR in the diagnosis of pulmonary and extra-pulmonary tuberculosis. National Journal of laboratory medicine. Natl J Lab Med. 2015;4(4):43-6.

15. Skoura E, Zumla A, Bomanji J. Imaging in extrapulmonary tuberculosis. Int J Infect Dis [Internet] 2015;32:87-93. Available from: https://doi.org/10.1016/j. ijid.2014.12.007

16. Al-Otaibi F, Hazmi MM El. Extra-pulmonary tuberculosis in Saudi Arabia. Indian J Pathol Microbiol. 2010;53(2):227-31.

17. Maji A, Misra R, Mondal AK, Kumar D, Bajaj D, Singhal A, et al. Expression profiling of lymph nodes in tuberculosis patients reveal inflammatory milieu at site of infection. Sci Rep. 2015;5(April):1-10. Available from: https://doi. org/10.1038/srep15214

18. Denkinger CM, Schumacher SG, Boehme CC, Dendukuri N, Pai MSK. Xpert MTB/RIF assay for the diagnosis of extrapulmonary tuberculosis: a systematic review and meta-analysis. Eur Respir J. 2014;44:435-46.

19. Noeske J, Yakam AN, Foe JA. Epid emiologie de la tuberculose au Cameroun telle qu ' elle est ' ee ' dans les donn ees ' de noti fi cation, 2006 - 2014 re fl et. Int J Tuberc Lung Dis. 2016;20(11):1489-94.

20. CDC. C D C division of global HIV \& TB Cameroon country profile strategic focus. 2018. p. 2018

21. WHO. The Stop TB Strategy: Building on and enhancing DOTS to meet the TB-related Millennium Development Goals. 2006.

22. Atekem KA, Tanih NF, Ndip RNNL. Evaluation of the tuberculosis control program in south West Cameroon: factors affecting treatment outcomes. Int J Mycobacteriol. 2018;7:137-42.

23. Mekonnen D, Derbie ADE. TB/HIV co-infections and associated factors among patients on directly observed treatment short course in northeastern Ethiopia: a 4 years retrospective study. BMC Res Notes. 2015;8:666.

Ready to submit your research? Choose BMC and benefit from:

- fast, convenient online submission

- thorough peer review by experienced researchers in your field

- rapid publication on acceptance

- support for research data, including large and complex data types

- gold Open Access which fosters wider collaboration and increased citations

- maximum visibility for your research: over $100 \mathrm{M}$ website views per year

At $\mathrm{BMC}$, research is always in progress.

Learn more biomedcentral.com/submissions 